\title{
Neurophysiology of the cough reflex
}

\author{
J.G. Widdicombe
}

Neurophysiology of the cough reflex. J.G. Widdicombe. CERS Journals Ltd 1995. ABSTRACT: Cough is due to activation of sensory receptors in the larynx and lower respiratory tract, sending impulses to the brainstem. The central organization of cough is poorly understood.

The afferent pathways for cough are from receptors in and under the epithelium of the airways. These receptors are rapidly adapting, with thin myelinated fibres in the vagus nerves, which can be directly stimulated by tussive agents. Activation of $\mathrm{C}$-fibre receptors in the airway releases sensory neuropeptides. These cause neurogenic inflammation and may activate rapidly adapting receptors to cause cough. The central connections of the $\mathrm{C}$-fibre receptors inhibit cough. Thus, the sensitivity of the cough reflex and its pattern of response is due to a complex interaction between $\mathrm{C}$-fibre receptors and rapidly adapting receptors, with peripheral and central nervous interactions.

How these mechanisms apply to clinical cough in patients is at present poorly understood, but is beginning to be clarified.

Eur Respir J., 1995, 8, 1193-1202.
Dept of Physiology, St George's Hospital Medical School, London, UK.

Correspondence: J.G. Widdicombe Dept of Physiology

St George's Hospital Medical School Cranmer Terrace

London SW17 ORE

Keywords: C-fibre receptors

cough

cough receptors

neuropeptides

rapidly adapting receptors tachykinins
The neurophysiology of cough was first studied in the early 19th century, after the discovery of the areas in the medulla oblongata that control breathing. As early as 1838, Muller [1] wrote "the medulla oblongata then excites to action the muscles which produce contraction of the glottis, and at the same time gives rise to spasmatic actions of the thorax and abdomen, during which time the glottis is partly opened and a loud noise produced". However, although it was clear that coughing was co-ordinated in the medulla oblongata, few experiments on cough were performed. This was probably mainly because with experimental animals the usual anaesthetic was morphine or opiates, which very powerfully inhibit cough. Some experiments were performed on unanaesthetized animals, for example by WILLIAMS [2] in 1840, who showed that insertion of a finger into the larynx of an unanaesthetized dog produced powerful expiratory efforts and closure of the glottis.

\section{Control nervous mechanisms}

Although the existence of a "cough centre" in the brainstem has frequently been postulated, there has never been any satisfactory analysis of the way such a centre interacts with the respiratory rhythm generator. Studies on brainstem neuronal activity during coughing are not definitive in this respect [3-7]. The main studies on the neurophysiology of cough have been to define the afferent pathways, leaving the central nervous system as a black box. The neuronal pathways of the respiratory rhythm generator have been intensively studied; the cough reflex can introduce a profound disorganization of the normal pattern of breathing, and yet the neuronal pathways by which afferents produce cough are unknown.
Cough, unlike sneeze and hiccup, is not stereotyped in pattern but can show a wide variety of forms [8,9]. These can, in general, be mimicked by voluntary action. Such voluntary control is thought, at least in part, to bypass the respiratory rhythm generator, although of course cough and normal respiratory rhythm cannot coexist [9]. In experimental animals, breathing can be depressed by general anaesthetics with little decrease in the power of cough reflex, and antitussive drugs can suppress cough with little depression of breathing [10, 11]. In humans, induced and natural cough can be suppressed voluntarily, although it is not known at what site in the central nervous system the suppression takes place [12-14].

In view of the importance and widespread use of antitussive agents thought to act directly on the central mechanisms of cough, it is important to have far more information about the brainstem neuronal pathways involved in this reflex. Some important pharmacological studies on the central representation of cough pathways have been carried out, in particular by KAMAI and co-workers [15-17]. The well-established antitussive action of opioids is mainly due to the subgroup $\mu_{2}$-opioid receptors in the mouse [15], but in addition $\kappa_{1}$ opioid receptors have a depressing action on cough in rats [16] and mice [17]. $\Delta$-opioid receptors do not seem to be involved in these species. It seems likely that the opioid antitussives work via 5-hydroxytryptamine receptors, probably $5 \mathrm{HT}_{1}$ rather than $5 \mathrm{HT}_{2}$ receptors. Thus, methysergide, given intracisternally, blocks the opioid antitussive action in rats, whereas ketaserin, a $5 \mathrm{HT}_{2}$ antagonist, has no effect [16]. A selective agonist of $5 \mathrm{HT}_{1 \mathrm{~A}}$ receptors has antitussive actions [18]. Other studies show that gaba-agonists have antitussive effects in 
cat and guinea-pig [19], and intracisternal N-methyl-Dasparate (NMDA) antagonists are antitussive in rats [20]. Intraperitoneal $\mathrm{Ca}^{2+}$-channel antagonists are also antitussive in guinea-pigs, and are thought to act via glutaminergic and NMDA receptors [21]. These important studies are beginning to show the mechanisms of action of the conventional opioid antitussives. They cannot at present be related to brainstem neurones responsible for cough, since the latter have not been identified. In addition, it is a pity that many of the studies have been with mice, which are said to be unable to cough, and rats, in which the main reflexogenic origin of cough is the larynx rather than the tracheobronchial tree (see below).

\section{Sites for eliciting cough}

The origin of cough is unique to structures innervated by the vagus nerves. These include the external ear, the oesophagus and abdominal organs. Cough due to diaphragmatic disease probably originates from adjacent vagally-innervated viscera, although this has not been established.

In experimental animals, the pattern of cough varies depending on which part of the respiratory tract is stimulated [5, 22]. Mechanical stimulation of the larynx causes immediate expiratory efforts, which are usually referred to as the "expiration reflex", rather than cough [5]. However, cough of a more classical nature can also be produced from the laryngopharyngeal region, including deep inspiratory efforts before the forced expirations. An interesting study in man by STоскwell et al. [23] has shown that bilateral block of the superior laryngeal nerves, which would interrupt the afferent supply from nearly all of the larynx, makes little difference to the cough threshold for inhaled citric acid aerosol in unanaesthetized humans, suggesting that the larynx is not an important tussigenic zone for this stimulus in man. In guinea-pigs, denervation of the larynx enhances the cough reflex due to inhaled citric acid aerosol or cigarette smoke [24]. This suggests that there could be an afferent supply from the larynx that inhibits cough and can be stimulated by irritants.

Stimulation lower down in the respiratory tract makes the inspiratory phase of coughing more prominent; indeed, the deep inspiratory efforts or augmented breaths that can be produced from the bronchial tree may resemble a fragment of an entire cough, in the opposite direction to the expiration reflex from the larynx. It may be these deep breaths that have been observed in the pharmacological studies on antitussive agents in rats and mice.

Teleologically, it would be desirable if a foreign body touching the vocal folds induced an immediate expiratory effort; a preliminary inspiration would draw the foreign body into the lungs. Conversely, debris in the bronchi would not be effectively cleared by cough unless a preliminary slow inspiration first drew air distal to the material before expulsion of the debris by forced expiration. In experimental animals, it is difficult to induce cough from the smaller airways and alveoli. Physiologically, this makes sense since the airflows and shear forces in the smaller airways would probably be inadequate to clear luminal debris. In man, BERGLUND [25] confirmed clinical observations first made by JACKSON [26], suggesting that bronchiolar and alveolar irritation does not cause cough. BERGLUND [25] stated: "If, in a patient with bronchopleural fistula, you inject contrast medium from the pleural into the bronchial tree during fluoroscopy, the patient does not start to cough until the contrast medium reaches the segmental bronchi".

\section{Stimuli to cough}

Another aspect of cough sensitivity in the lower airways relates to the nature of the stimulus for the reflex. In the cat, the receptors in the larynx and trachea are extremely sensitive to mechanical stimuli, with a very rapid adaptation rate and an "off" response, rather like the behaviour of Pacinian corpuscles [27-29]. The receptors do not accommodate to repeated stimulations, which may explain the embarrassing persistence of the "dry cough" of laryngitis and tracheitis. Lower down the airways, the receptors become more chemosensitive and less mechanosensitive, and show pronounced accommodation to repeated stimuli. The extent to which these observations apply to man is uncertain, but if they do, they may explain some of the various cough responses that can be induced from different parts of the respiratory tract. Thus, in man the threshold for cough with capsaicin aerosol becomes lower with small particles [30], presumably because the aerosol can penetrate deeper into the lung and stimulate the more chemosensitive cough receptors there. However, in general, when aerosols are administered in man to test coughing, there is little information as to whether they act at the larynx, the trachea or the larger bronchi. Inflammation and other pathologies of the larynx, trachea and larger bronchi are powerful stimuli for coughing [5, 8]. However, diseases at the alveolar level, such as pulmonary congestion and oedema, fibrosis and sarcoidosis, are not especially characterized by cough [8]; this is consistent with the experimental evidence that there are few or no receptors for coughing at distal sites.

Coughing is not only produced in a variety of airway diseases, but the diseases may enhance the cough responses to an inhaled irritant aerosol. FULLER and CHOUDRY [31] studied the cough response to capsaicin in healthy subjects, those with nonproductive cough, and those with productive cough. The last group had the same capsaicin threshold for cough as the healthy subjects, but the patients with nonproductive cough had a greatly sensitized cough reflex. This observation has a counterpart in studies with experimental animals, where the airway receptors probably responsible for cough increase their rate of firing and sensitivity if airways inflammation is caused by a drug, such as histamine [32].

\section{Histology of "cough receptors"}

It has long been known that the airway epithelium contains sensory nerve fibres which are presumed to mediate cough. These can be seen under the electron 


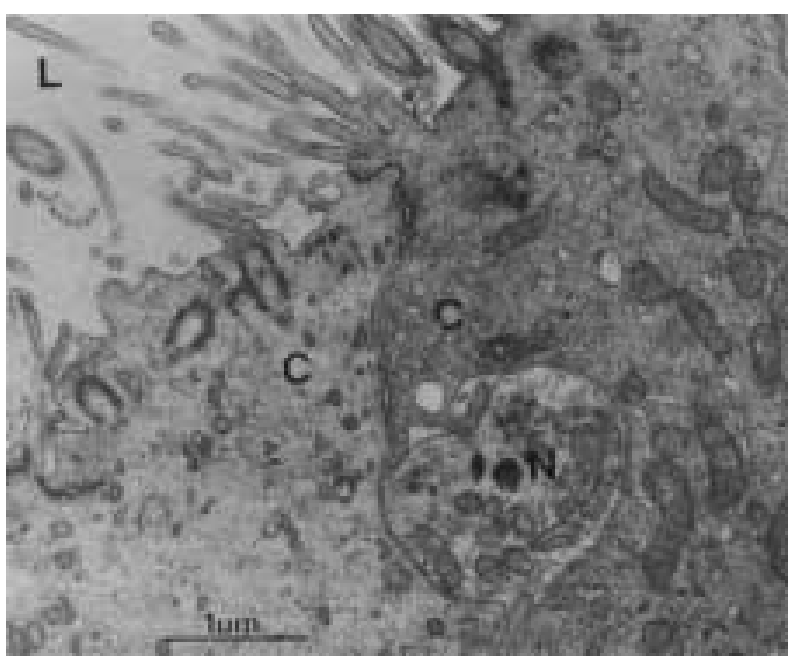

Fig. 1. - Axon profile (N) with mitochondria and vesicles located closely to the airway lumen (L) between two ciliated cells (C), human tissue. (Internal scale bar=1 $\mu \mathrm{m}$; magnification $\times 24,600$ ). (From [35]).

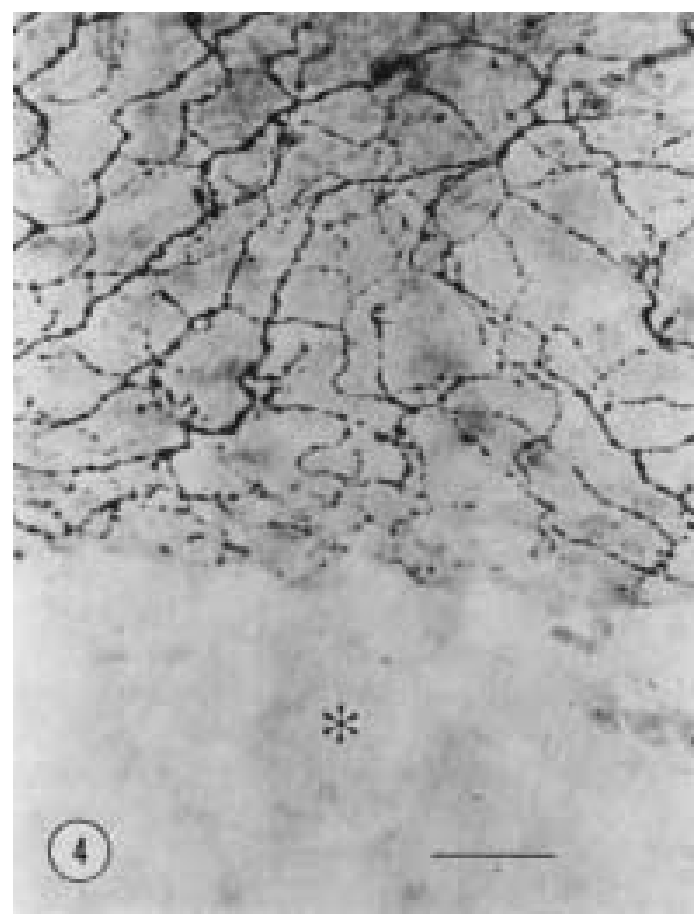

Fig. 2. - A region of the tracheal mucosa directly above a cartilaginous ring of a rat. Nerves are exhibited by immunofluorescence for substance P. The density and orientation of the intraepithelial plexus of substance P-immunoreactive (SP-IR) axons are similar to those found between the cartilaginous rings. The intraepithelial nerve plexus is absent in a region of the epithelium $(*)$, which was accidentally removed during processing. (Internal scale bar=20 $\mu \mathrm{m}$ ). (From [36]).

microscope [33, 34] (fig. 1), and more recently have been studied by immunofluorescent techniques. BALUK and co-workers [36] showed that the tracheal epithelium of the rat has an extensive plexus of nerves which stain both for substance $\mathrm{P}$ (SP) and for calcitonin generelated peptide (CGRP) [37] (fig. 2). Most of these nerves lie in the basal region of the epithelium, and some send processes up towards the lumen, often with splayed terminals. Electron microscopic studies show that these nerves are only found deep to the tight junc- tions between epithelial cells $[33,34,35]$. The majority of them can be shown to be sensory by degeneration experiments [36, 38].

The nerves are thought to mediate neurogenic inflammation, the axon reflex set up by irritation of the nerve terminals in the epithelium and mucosa [39-41]. The nerves branch to mucus secreting glands, blood vessels and possibly airway smooth muscle and autonomic ganglia (fig. 3). Their activation will release sensory neuropeptides (tachykinins), such as SP, neurokinin A (NKA) and CGRP. These in turn cause vasodilatation and exudation of plasma, and possibly oedema, epithelial damage and submucosal gland secretion; at least in the guinea-pig there is also smooth muscle contraction. These features define neurogenic inflammation. But, in addition, when stimulated the receptors will send impulses up to the central nervous system to produce cough and an array of motor responses [28].

BALUK and co-workers [36] showed that if the epithelium is stripped from the mucosa of the rat, the SP-containing nerves disappear (fig. 2). This is an observation of great interest and importance. Others have shown that in asthma the airway epithelium can be damaged or even absent $[43,44]$. If this results in the disappearance of SP-containing nerves responsible for cough, then the cough reflex should be abolished. In fact, it is enhanced. There are several possible explanations for this paradox. One is that, although stripping the epithelium removes the vast majority of mucosal sensory nerves, the few remaining in the submucosa can be sensitive enough to enhance the cough reflex. Alternatively, it may be nerves containing neuropeptides other than SP that are important in causing cough. In this respect, it is relevant that two studies have shown that the content of SP and CGRP in mucosal nerves can be increased in conditions when cough is also enhanced; in one case in human asthma [45], and in the other in response to cigarette smoke in experimental animals [46]. Thus, what is important may be not only the number of nerves present but their sensitivity and the amounts and types of neuropeptide they contain.

A fundamental question is whether the nerves identified histologically in the epithelium are parts of cough receptors. Some comparative histological studies support this view. Table 1 shows the counts of nerves in the epithelium at different levels of the airways. The cat has been most frequently studied, and there is a concentration of nerves at the carina [34], the most sensitive site for eliciting the cough reflex in the lower airways of this species [22]. Apart from man, few or no fibres have been identified in the intrapulmonary airways, consistent with the view that cough is difficult to induce from this site. Of interest is the fact that the mouse and the ferret lack intraepithelial nerves [47, 48], and these are two species which have no cough reflex from the tracheobronchial tree [5]. However, the rat has many intraepithelial nerves [36], and the rat does not cough when its trachea or bronchi are irritated [5]. Instead, it shows hyperventilation and tachypnoea. No species has been identified which lacks epithelial nerves but can cough when the tracheobronchial mucosa is irritated. 


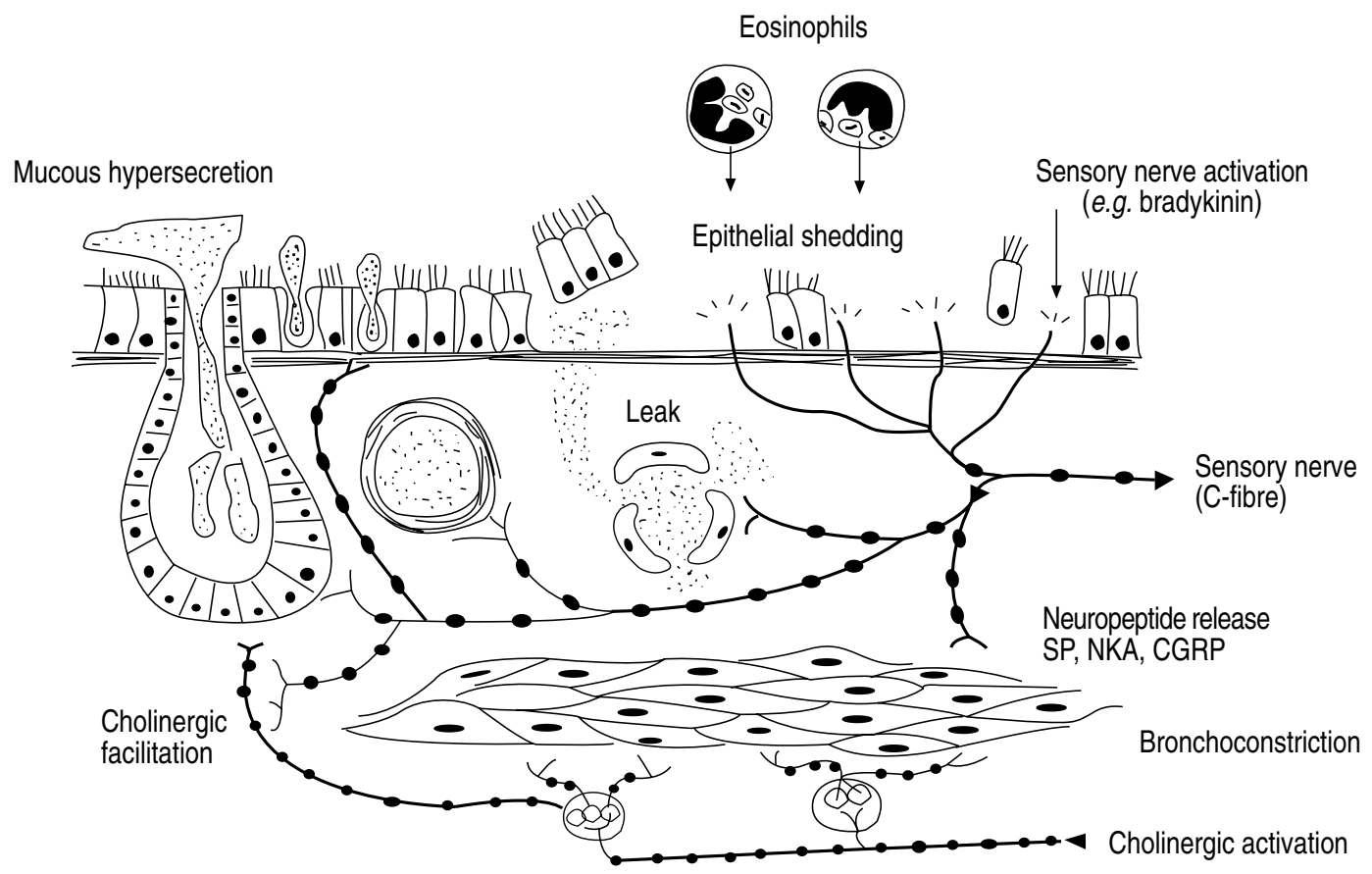

Fig. 3. - Possible axon reflex mechanisms (neurogenic inflammation) in asthma. SP: substance P; NKA: neurokinin A; CGRP: calcitonin generelated peptide. (From [42]).

Thus, the general conclusion is that the epithelial nerves in the lower airways can cause cough, hyperventilation, tachypnoea, or augmented breaths, depending on the species and site of stimulation.

\section{Afferent pathways for cough}

If we assume that the intraepithelial nerves cause cough, then they need to be correlated with the vagal afferent fibres studied by recording nerve impulses. With respect to the sensory nerves in the tracheobronchial tree and lungs in experimental animals, including man, five different types of receptor have been identified (table 2) [28, 29]. Of these, slowly adapting pulmonary stretch receptors influence the pattern of breathing, but there is no evidence that they are directly involved in coughing; they are not excited by irritant stimuli that cause cough. They may enhance the cough reflex by a central nervous action but they do not cause it [49]. Sensory nerves associated with neuroepithelial bodies have not been

Table 1. - Nerves in the airway epithelium of different species

Concentrations of nerves $\cdot \mathrm{mm}^{-1}$ epithelium

\begin{tabular}{lcccc} 
& & & \multicolumn{2}{c}{ Bronchi } \\
\cline { 4 - 5 } Species & Trachea & Carina & $\begin{array}{c}\text { Extra- } \\
\text { pulmonary }\end{array}$ & $\begin{array}{c}\text { Intra- } \\
\text { pulmonary }\end{array}$ \\
\hline Cat & 41 & 76 & 17 & 0 \\
Rat & 48 & $?$ & 30 & 0 \\
Man & 9 & $?$ & 8 & 4 \\
Mouse & 0 & 0 & 0 & 0 \\
Ferret & 0 & 0 & 0 & 0 \\
\hline
\end{tabular}

(From [34, 35, 47, 48]). ?: unknown.
Table 2. - Types of sensory receptors in the lungs and lower respiratory tract

\begin{tabular}{lll}
\hline Receptor & \multicolumn{1}{c}{ Site } & Fibre \\
\hline Slowly adapting stretch & Smooth muscle airway & $\mathrm{A} \alpha-\beta$ \\
Rapidly adapting stretch & Airway epithelium & $\mathrm{A} \delta$ \\
Pulmonary C-fibre & Alveolar wall & $\mathrm{C}$ \\
Bronchial C-fibre & Airway wall & $\mathrm{C}$ \\
Neuroendocrine body & Airway epithelium & $?$ \\
\hline
\end{tabular}

greatly studied, and there is no evidence that they are stimulated by irritants that produce coughing or that their reflex action is cough.

The three most likely candidates for cough receptors are the rapidly adapting pulmonary stretch receptors (RARs, sometimes called irritant receptors) with small diameter $(\mathrm{A} \delta)$ myelinated fibres, and the pulmonary and bronchial C-fibre receptors with nonmyelinated afferents. The evidence that the RARs cause cough is based on their localization at the sites of the airway most sensitive for cough (larynx and carina) [27, 34], the fact that all the mechanical and chemical stimuli that lead to cough also excite them $[28,50]$, and the observation that many of the nonmyelinated fibres in the epithelium are connected to myelinated fibres in the vagal trunks [51].

There has been considerable discussion as to whether C-fibre receptors also cause cough [28, 52]. It seems unlikely that those in the alveoli and bronchioles do so. It is difficult to initiate cough from these areas, and cough induced from this region would not clear the alveoli or bronchioles of luminal debris. Indeed, stimulation of pulmonary C-fibre receptors in the cat inhibits the cough reflex induced by mechanical stimulation of the larynx or the trachea [53] (fig. 4). In man, systemic 
EMG

a)

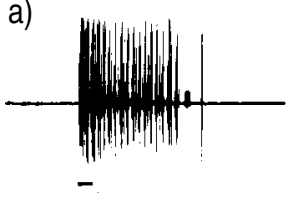

b)
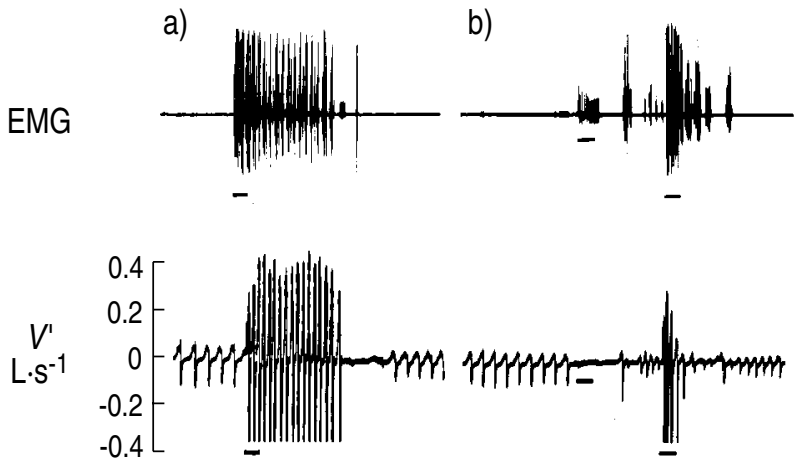

$\mathrm{BP}$

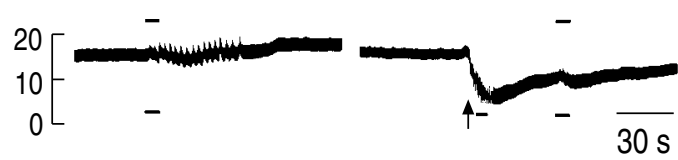

Fig. 4. - Effect of pulmonary C-fibre reflex on coughing induced from the tracheobronchial tree of unanaesthetized cat. Traces from above down: electromyographic activity (EMG) of genioglossus muscle; airflow $\left(V^{\prime}\right)$ from tracheal cannula; and systemic arterial blood pressure (BP). a) The tracheobronchial mucosa was stimulated mechanically during the signal marks, causing increased EMG activity and airflow, corresponding to cough efforts. The cough efforts continued long after the stimulus had stopped. b) Phenylbiguanide $\left(25 \mu \mathrm{g} \cdot \mathrm{kg}^{-1}\right)$ was injected intravenously at the arrow, causing hypotension, bradycardia and apnoea due to stimulation of pulmonary C-fibre receptors. During the apnoea at the signal marks the tracheobronchial stimulus was repeated, causing no change in airflow but some increase in EMG activity. Later, during the phase of rapid shallow breathing, the tracheobronchial stimulus was repeated and caused four cough efforts, with no coughing after the end of the stimulus. (From [53]). 5-hydroxytrypamine (5-HT), known to excite pulmonary C-fibre receptors in animals, can inhibit the cough due to inhaled citric acid [54].

It is more plausible that the bronchial C-fibre receptors could mediate cough. Their site is appropriate and they respond to the same mediators and irritants as do the RARs and pulmonary C-fibre receptors [28]. There is, however, evidence that bronchial C-fibre receptors, like those at the pulmonary level, inhibit cough $[55,56]$. As shown in table 3, virtually all the same stimuli activate all three groups of receptor. This is not surprising. Most tissues, somatic and visceral, have both thin myelinated $(\mathrm{A} \delta)$ and $\mathrm{C}$-fibre afferents, that respond to tissue damage and inflammatory mediators and produce appropriate reflex actions [57].

\section{Reflex responses}

Whereas in general the C-fibre afferents are thought to mediate neurogenic inflammation, both they and RARs cause central nervous reflexes. The central nervous responses can interact and gating mechanisms have been much studied for somatic sensory pathways, with afferent inputs inhibiting the reflexes due to $\mathrm{A} \delta$ and $\mathrm{C}$ fibres [58]. Whether gating mechanisms also exist for the afferent pathways from the lungs and airways has not been much studied, but is an important question. Pulmonary C-fibre activation can inhibit spinal reflexes [59] and cough [53]. If C-fibre stimulation closes the gate of the cough reflex, pharmacological activation of the receptors might be a useful therapeutic antitussive tool. An analogy may be seen in the antitussive actions

Table 3. - Stimuli to C-fibre receptors and RARs

\begin{tabular}{|c|c|c|c|}
\hline \multicolumn{4}{|c|}{ C-fibre receptors } \\
\hline & Pulmonary & Bronchial & RARs \\
\hline \multirow[t]{5}{*}{ Mechanical } & Inflation & Foreign bodies & Inflation \\
\hline & Foreign bodies & & Deflation \\
\hline & & & Dust \\
\hline & & & Mucus \\
\hline & & & Foreign bodies \\
\hline \multirow[t]{4}{*}{ Chemical } & Irritant gases & Irritant gases & Irritant gases \\
\hline & Cigarette smoke & & Cigarette smoke \\
\hline & Capsaicin & & Capsaicin \\
\hline & Volatile anaesthetics & & Volatile anaesthetics \\
\hline \multirow[t]{6}{*}{ Mediators } & Acetylcholine & Histamine & Acetylcholine \\
\hline & Histamine & Serotonin & Histamine \\
\hline & Serotonin & Prostaglandins & Serotonin \\
\hline & Prostaglandins & Bradykinin & Prostaglandins \\
\hline & Bradykinin & & Bradykinin \\
\hline & Substance $\mathrm{P}$ & & Substance P \\
\hline \multirow{5}{*}{ Diseases } & Microembolism & Pulmonary congestion & Anaphylaxis \\
\hline & Pulmonary oedema & & Microembolism \\
\hline & Pulmonary congestion & & Atelectasis \\
\hline & Pneumonia & & Bronchoconstriction \\
\hline & & & Pulmonary oedema \\
\hline
\end{tabular}

In general the three groups of receptor respond to the same stimuli. However, sensitivities vary greatly. The main differences in response relate to mechanical stimuli. The lists of chemical and mediator stimuli are incomplete, and not all agents have been tested on all groups of receptors. RAR: rapidly adapting receptor. 
Table 4. - Reflex responses to receptor stimulation

\begin{tabular}{|c|c|c|}
\hline \multicolumn{2}{|c|}{ C-fibre receptors } & RARs \\
\hline Apnoea & Apnoea & Cough \\
\hline Tachypnoea & Tachypnoea & Tachypnoea \\
\hline Cough inhibition & & Augmented breaths \\
\hline Bronchoconstriction & Bronchoconstriction & Bronchoconstriction \\
\hline Mucus secretion & Mucus secretion & Mucus secretion \\
\hline Laryngoconstriction & & Laryngoconstriction \\
\hline Vasodilation & & Vasodilation \\
\hline Somatic inhibition & & \\
\hline
\end{tabular}

The main differences between the reflex responses are respiratory. The lists may be incomplete because not all reflexes have been studied for the three groups of receptor. RAR: rapidly adapting receptor.

of menthol vapour. This inhibits cough [60], but stimulates sensory receptors in the larynx [61] and nose [62]. There is no evidence that menthol inhibits cough or other sensory receptors, and the inhibition of cough could be via a central gating mechanism [60].

The reflex responses found in experimental animals on stimulation of the three groups of receptors are shown in table 4 [28, 29, 50]. Most of the autonomic nervous changes are the same for the three groups, but a striking difference applies to the respiratory effects. Whereas all the evidence points to RARs causing cough, neither pulmonary nor bronchial C-fibre receptors have ever been shown to do so. Indeed, their selective stimulation in anaesthetized and unanaesthetized animals always causes apnoea and rapid shallow breathing.

\section{The role of $\mathrm{C}$-fibre receptors in cough}

Experimental evidence that $\mathrm{C}$-fibre receptor activation can inhibit cough has already been given. The claim that C-fibre receptors may cause cough is based largely on experiments with capsaicin, the pungent extract of red peppers, which can stimulate pulmonary and bronchial C-fibre receptors. In dozens of experimental projects where this agent has been given systemically in anaesthetized and unanaesthetized animals, cough has never been elicited [52], except in one study with conscious humans [63]. When capsaicin is given as an aerosol, it is a powerful tussigenic agent in man and other animals, and it is now used as a standard method for eliciting cough. In one study in dogs, capsaicin aerosol inhibited cough [56]; concentration and species may be important. Moreover, capsaicin is certainly not specific for $\mathrm{C}$-fibre receptors and probably not very selective. Systemically and as an aerosol it stimulates RARs [64, 65], and the most plausible hypothesis is that it is causing cough in this way.

Other arguments that C-fibre receptors may cause cough come from the work of ForsBERG et al. [66]. They studied cough in guinea-pigs due to inhaled citric acid, capsaicin, nicotine and mechanical stimulation of the trachea. Large doses of capsaicin depleted the sensory nerves in the lungs of SP and CGRP, and blocked the cough reflex due to citric acid and capsaicin, but not that due to nicotine and mechanical stimulation. They arg- ued that the first two stimuli acted via $\mathrm{C}$-fibre receptors and the last two via RARs, both of which receptors are claimed to cause cough $[66,67]$. However, large doses of capsaicin can damage or destroy $\mathrm{A} \delta$ myelinated fibres as well as C-fibres [68]. In the absence of physiological evidence (e.g. fibre recording) on which afferent pathways were activated by the tussive stimuli and which were blocked by large doses of capsaicin, the results are not definitive in terms of mechanisms. They show that different patterns of afferent activation can result in various types of cough, a conclusion consistent with an alternative hypothesis (see below).

\section{Tachykinins and cough}

This hypothesis is that capsaicin may act on both RARs and C-fibre receptors (fig. 5), with release of tachykinins from the latter that, in turn, further stimulate RARs, which enhances cough. Tachykinins are only weak tussive agents when given by aerosol in animals [69, 70] and humans [71], or may have no such action at all [72]. This may be because they have difficulty in penetrating the airway epithelium; in particular, they would have to

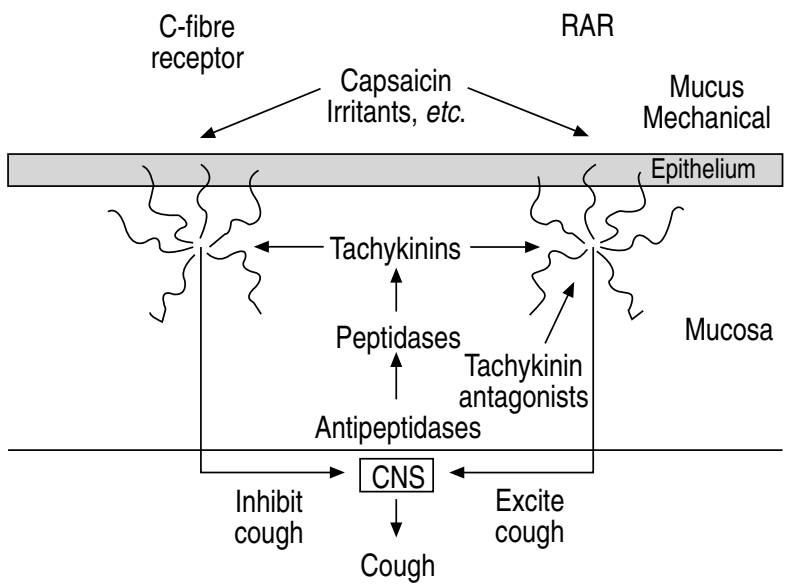

Fig. 5. - Diagram of hypothetical role for tachykinins in cough. Tachykinins may be released from C-fibre receptors, and diffuse to RARs, which they stimulate to cause cough. They can be broken down by peptidases, which in turn can be inhibited by antipeptidases. Tachykinin antagonists can prevent the action of tachykinins on the RARs. If there is sufficient stimulation of C-fibre receptors, these can cause a central inhibition of cough. CNS: central nervous system; RAR: rapidly adapting receptor. 
pass the barrier of peptidases that lies at the base of the epithelium [73]. In one study, SP aerosols given to humans, healthy or with asthma, did not cause cough, but caused the sensation of tightness in the chest of the asthmatics, possibly secondary to bronchoconstriction and indicating that some sensory nerves were being stimulated [72]. In other studies, SP aerosols caused cough in patients with upper airway infection but not in healthy subjects [71, 74]; the former may have had damaged epithelium, with easier penetration of the SP. Endogenous tachykinins released by activation of $\mathrm{C}$ fibre receptors in the epithelium and mucosa could diffuse to RARs more readily and in higher concentrations.

This general view that tachykinins are involved in cough is supported by the observations that tachykinin antagonists block the cough caused by citric acid and cigarette smoke, and that SP-antagonists block the cough caused by bradykinin in patients during infection with pertussis or with chronic obstructive pulmonary disease (COPD) [75-77]. C-fibre receptors can be stimulated by citric acid, cigarette smoke and bradykinin to release tachykinins [78]. Thus, the tachykinin antagonists may prevent the action of neurokinins on RARs. Such an action has been established by recording from single fibres from RARs in rabbits by PRABHAKAR et al. [79], who showed that systemic SP not only caused reflex changes characteristic of stimulation of lung RARs but also increased the impulse frequency in vagal single fibres coming from RARs.

Results with peptidase inhibitors support a role for endogenous tachykinins in cough. In many human subjects, angiotensin converting enzyme (ACE) inhibitors cause cough, presumably by preventing the breakdown of endogenous tachykinins or bradykinin $[80,81]$. The peptidase inhibitor phosphoramidon not only causes cough in guinea-pigs, but enhances the cough response to inhaled SP [69, 76].

If endogenous tachykinins are released from C-fibre receptors and can cause cough, the hypothesis that these receptors induce cough by their direct nervous connections to the brainstem becomes implausible. It would require a positive feedback with neuropeptides stimulating the nerves that release them. This is possible but seems unlikely, since the reaction might become explosive. There seems to be no similar mechanism in neurophysiology, with two possible and significant exceptions. SP is said to stimulate pulmonary C-fibre receptors in the rabbit, which might release more SP [79]. And in dorsal root ganglia CGRP opens calcium channels, which in turn might lead to the release of CGRP from the neurone [82].

\section{RAR/C-fibre receptor interactions in cough}

RARs in the larynx and the tracheobronchial tree are the primary sensory pathways for cough, and C-fibre receptors cause neurogenic inflammation and by their own reflex action inhibit cough by a central gating mechanism. In addition, the tachykinins released from the Cfibre receptors can activate the RARs. Thus, a complex mechanism of interaction exists. The end result will depend on the degree of activation of C-fibre receptors and RARs by the tussive stimuli, and the relative balance of stimulation of RARs directly by the tussive stimuli, indirectly by tachykinins released from C-fibre endings, and the central inhibition of cough by C-fibre reflex action. This interplay may explain the different patterns of cough seen with different chemical and irritant stimuli and arising from different parts of the respiratory tract. A weak stimulation of C-fibre receptors might potentiate cough by local mechanisms, and a strong stimulation might inhibit it by central reflex actions; this process could have teleological advantages.

A similar argument applies to the reflex pathways for bronchoconstriction and for sensation from the lungs. Bronchoconstriction can be dissociated from cough, but involves interactions between the same afferent pathways [53]. Airway sensation probably also involves sensory input interactions [83]. The complexity of afferent inputs to cough may also provide the basis for a curious phenomenon: capsaicin is an ingredient of antitussive remedies, such as Fisherman's Friend; given as an aerosol it is usually a powerful stimulus to cough, although in some circumstances it can inhibit cough [56].

\section{Clinical cough}

It is difficult to analyse the neurophysiological mechanisms underlying cough in human subjects and patients, and it is not the purpose of this review to speculate greatly on this issue. In general, studies on cough in patients give results consistent with the mechanisms analysed in experimental animals, as described above. Some examples will be mentioned briefly, and detailed reviews can be referred to [7, 84-88].

\section{Acute and chronic nonasthmatic cough}

By far the most common cause of acute cough is respiratory tract infection [89-92]. The cough threshold to inhaled irritants is reduced in this condition. The epithelium may be damaged, so that irritants may penetrate more readily and endopeptidases may be reduced allowing greater concentration of endogenous tachykinins to stimulate RARs. The histopathology is consistent with airways neurogenic inflammation described above. Similar mechanisms may be present in chronic cough without obvious infection [89-91].

\section{Postnasal drip syndrome}

Here, it is likely that secretions including inflammatory mediators penetrate to the larynx, and possibly to the trachea, and stimulate the afferent limb of the cough reflex in the upper respiratory tract [93]. It is unlikely that the cough arises from pharyngeal irritation, although a sore throat may be the main symptom. Cough has never been directly initiated from the pharynx or other upper airway structure above the larynx. The pharynx is innervated by the glossopharyngeal nerves, and not the vagi to which the cough pathway is restricted. 


\section{Asthma}

Asthma is an inflammatory condition of the airways, and the processes that activate sensory receptors in the airways will cause cough $[94,95]$. These include inhaled allergens and the wide variety of inflammatory mediators which are known to stimulate RARs and C-fibre receptors.

\section{Gastro-oesophageal reflux}

This is a common cause of chronic cough. The possibility that acid reflux is inhaled into the tracheobronchial tree is unlikely. Most evidence points to the cough reflex caused by activation of sensory receptors in the distal oesophagus [96-98]. This organ is vagally innervated, and thus is potentially a tussigenic area. The cough is inhibited by agents such as aerosolized ipratropium bromide [98], possibly by prevention of the secretion of airway mucus due to the oesophageal reflex.

\section{Chronic bronchitis}

Here, the cough may be due to inflammatory processes in the airway mucosa, plus the secretion of mucus which is a powerful stimulant to RARs.

\section{Angiotensin-converting enzyme inhibitors}

These have already been mentioned as a cause of cough. When airway peptidises are inhibited, endogenous agents, such as bradykinin and the tachykinins, can accumulate and stimulate sensory nerves that induce coughing [60, 61].

\section{Conclusions}

In conclusion, cough and its patterns depend on an interplay between sensory receptors in the airway mucosa, the sites of the mucosa being irritated to cause cough, and central nervous mechanisms including gating with unknown connections and interactions with the brainstem respiratory rhythm generator. This concept raises important questions. What are the central nervous pathways and interactions, and how do central antitussive drugs work? How is neurogenic inflammation related to stimulation of RARs, and is there scope for therapeutic approaches at this level? How are the sensitivities and responses of mucosal sensory receptors influencing cough affected by tissue damage and local inflammatory responses in disease? How can the analytical results on experimental animals be applied to humans, healthy or with cough due to disease? The subject is of considerable physiological, pathological and therapeutic importance.

\section{References}

1. Muller J. In: Elements of Physiology. London, Taylor and Walton, 1838; pp. 343-358.
2. Williams CJB. In: The Pathology and Diagnosis of Diseases of the Chest. London, Churchill, 4th edn. 1840; pp. 43-75.

3. Jakus J, Tomori Z, Stransky A. Activity of bulbar respiratory neurones during cough and other respiratory tract reflexes in cats. Physiol Bohemoslov 1985; 34: 127-136.

4. Engelhorn R, Weller E. Zentrale representation hustenwirksamer Afferenzen in der Medulla oblongata der Katze. Pflugers Arch Ges Physiol 1965; 284: 224-239.

5. Korpas J, Tomori Z. In: Cough and Other Respiratory Reflexes. Basel, S. Karger, 12th edn. 1979; pp. 1356.

6. Dawid-Milner MS, Lara JP, Milan A, Gonzalez-Baron S. Activity of inspiratory neurones of the ambiguus complex during cough in the spontaneously breathing decerebrate cat. Exp Physiol 1993; 78: 835-838.

7. Irwin RS, Widdicombe JG. Cough. In: Murray JF, Nadel JA, eds. Textbook of Respiratory Medicine. Philadelphia, W.B. Saunders Co., 2nd edn. 1994; pp. 529-544.

8. Kase Y, Wakita Y, Kito G, Miyata T, Yuizozno T, Kataoka M. Centrally induced coughs in the cat. Life Sci 1970; 9: 49-59.

9. Davis JN. Autonomous breathing. Arch Neurol 1974; 30: 480-484.

10. May AJ, Widdicombe JG. Depression of the cough reflex by pentobarbitone and some opium derivatives. $\mathrm{Br}$ J Pharmacol 1954; 9: 335-340.

11. Salem H, Aviado DM (eds). Antitussive Agents. In: International Encyclopedia of Pharmacology and Therapeutics. Oxford, Pergamon Press Ltd, 1970; pp. 1298.

12. Hutchings HA, Eccles R. The opioid agonist codeine and antagonist naltrexone do not affect voluntary suppression of capsaicin induced cough in healthy subjects. Eur Respir J 1994; 7: 715-719.

13. Hutchings HA, Eccles R, Smith AP, Jawad MSM. Voluntary cough suppression as an indication of symptom severity in upper respiratory tract infections. Eur Respir J 1993; 6: 1449-1454.

14. Hutchings HA, Morris S, Eccles R, Jawad MSM. Voluntary suppresion of cough induced by inhalation of capsaicin in healthy volunteers. Respir Med 1993; 87: 379_ 382.

15. Kamai J, Iwamoto Y, Suzuki T, Misawa M, Nagase H, Kasuya $Y$. The role of the $\mu_{2}$-opioid receptor in the antitussive effect of morphine in $\mu_{1}$-opioid receptor deficient CXBK mice. Eur J Pharmacol 1993; 240: 99-101.

16. Kamai J, Tanihara H, Kasaya Y. Antitussive effects of two specific $\kappa$-opioid agonists, U-50,488H and U-62, 066E, in rats. Eur J Pharmacol 1990; 187: 281286.

17. Kamai J, Iwamoto Y, Misawa M, Nagase HC, Kasuya Y. Antitussive effect of $\left(\mathrm{Met}^{5}\right)$ enkephlin-Arg6-Phc ${ }^{7}$ in mice. Eur J Pharmacol 1994; 253: 293-296.

18. Kamai J, Mori T, Igarashi H, Kasuya Y. Effects of 8-hydroxy-2-(di-2-propylamino) tetralin, a selective agonist of $5-\mathrm{HT}_{1 \mathrm{~A}}$ receptors, on the cough reflex in rats. Eur J Pharmacol 1991; 203: 253-258.

19. Bolser DC, Aziz SM, Degennaro FC. Antitussive effects of Gaba agonists in the cat and guinea-pig. Br J Pharmacol 1993; 110: 491-495.

20. Kamai J, Tanihara H, Igarashi H, Kasma Y. Effects of $\mathrm{N}$-methyl-D-asparate antagonists on the cough reflex. Eur J Pharmacol 1989; 168: 153-158.

21. Kamai J, Kasma Y. Antitussive effects of $\mathrm{Ca}^{2+}$ channel antagonists. Eur J Pharmacol 1992; 212: 61-66. 
22. Widdicombe JG. Respiratory reflexes from the trachea and bronchi of the cat. J Physiol 1954; 123: 55-70.

23. Stockwell M, Lang S, Yip R, Zintel T, White C, Galagher CG. Lack of importance of the superior laryngeal nerves in citric acid cough in humans. J Appl Physiol 1993; 75: 613-617.

24. Forsberg K, Karlsson JA, Lundberg JM, Zackrisson C. Effect of laryngeal denervation on irritant induced cough and bronchoconstriction in conscious guinea-pig. J Physiol 1990; 422: 34.

25. Berglund E. In: Cough and Expectoration. Munksgaard; European Journal of Respiratory Diseases, 1980; 61st edn. p. 20.

26. Jackson C. Cough: bronchoscopic observations on the cough reflex. J Am Med Assoc 1922; 79: 1399-1403.

27. Widdicombe JG. Receptors in the trachea and bronchi of the cat. J Physiol 1954; 123: 71-104.

28. Coleridge HM, Coleridge JCG. Reflexes evoked from the tracheobronchial tree and lungs. In: Cherniack NS, Widdicombe JG, eds. Handbook of Physiology. 3. The Respiratory System. Vol. II. Control of Breathing. Bethesda, American Physiological Society, 1986; pp. 395-429.

29. Sant'Ambrogio G. Information arising from the tracheobronchial tree of mammals. Physiol Rev 1982; 62: 531-569.

30. Hansson L, Wollmer P, Dahlback M, Karlsson J-A. Regional sensitivity of human airways to capsaicin-induced cough. Am Rev Respir Dis 1992; 145: 1191-1195.

31. Fuller RW, Choudry NB. Patients with a nonproductive cough have an increased cough reflex. Thorax 1988; 43: 256-261.

32. Sellick H, Widdicombe JG. Stimulation of lung irritant receptors by cigarette smoke, carbon dust, and histamine aerosol. J Appl Physiol 1971; 31: 15-19.

33. Laitinen L. Detailed analysis of the neural elements in human airways. In: Kaliner M, Barnes PJ, eds. Neural Regulation of the Airways in Health and Disease. New York, Marcel Dekker, 1986; pp. 35-36.

34. Das RM, Jeffery PK, Widdicombe JG. The epithelial innervation of the lower respiratory tract of the cat. $J$ Anat 1978; 126: 123-131.

35. Laitinen A. Autonomic innervation of the human respiratory tract as revealed by histochemical and ultrastructural methods. Eur J Respir Dis 1985; 140: 1-42.

36. Baluk P, Nadel JA, McDonald DM. Substance Pimmuno-reactive sensory axons in the rat respiratory tract: a quantitative study of their distribution and role in neurogenic inflammation. J Comp Neurol 1992; 319: 586598.

37. Baluk P, Nadel JA, McDonald DM. Calcitonin generelated peptide in secretory granules of serous cells in the rat tracheal epithelium. Am J Respir Cell Mol Biol 1993; 8: 446-453.

38. Das RM, Jeffery PK, Widdicombe JG. Experimental degeneration of intraepithelial nerve fibres in cat airways. J Anat 1979; 128: 259-263.

39. McDonald DM. The concept of neurogenic inflammation in the respiratory tract. In: Kaliner MA, Barnes PJ, Kunkel GHH, Baraniuk JN, eds. Neuropeptides in Respiratory Medicine. New York, Marcel Dekker, 1994; pp. 321-349.

40. McDonald DM. Neurogenic inflammation in the respiratory tract: Actions of sensory nerve mediators on blood vessels and epithelium of the airway mucosa. Am Rev Respir Dis 1987; 136: S65-S71.

41. McDonald DM. Effects of infection on neurogenic microvascular permeability in the airway. Am Rev Respir Dis 1992; 146: S40-S44.

42. Barnes PJ. Airway NANC nerves and neuropeptides. In: Barnes PJ, Rodger IW, Thomson NC, eds. Asthma. Basic Mechanisms and Clinical Management. London, Academic Press, 1992; pp. 359-389.

43. Laitinen LA, Heino M, Laitinen A, Kava T, Haahtela T. Damage of the airway epithelium and bronchial reactivity in patients with asthma. Am Rev Respir Dis 1985; 131; 599-606.

44. Laitinen LA, Laitinen A. Overview of the pathology of asthma. In: Page CP, Barnes PJ, eds. Pharmacology of Asthma. Handbook of Experimental Pharmacology. New York, Springer-Verlag, 1991; pp. 1-25.

45. Ollerenshaw SL, Jarvis D, Sullivan CE, Woolcock AJ. Substance P immunoreactive nerves in airways from asthmatics and nonasthmatics. Eur Respir J 1991; 4: 673-682.

46. Karlsson JA, Zackrisson C, Lundberg JM. Hyperresponsiveness to tussive stimuli in cigarette smoke-exposed guinea-pigs: a role for capsaicin-sensitive, calcitonin gene-related peptide-containing nerves. Acta Physiol Scand 1991; 141: 445-454.

47. Pack RJ, Al-Ugaily LH, Widdicombe JG. The innervation of the trachea and extrapulmonary bronchi of the mouse. Cell Tissue Res 1984; 238: 61-68.

48. Robinson NP, Venning L, Kyle H, Widdicombe JG. Quantitation of the secretory cells of the ferret tracheobronchial tree. Anat 1986; 145: 173-188.

49. Hanacek J, Davies A, Widdicombe JG. Influence of lung stretch receptors on the cough reflex in rabbits. Respir 1984; 45: 161-168.

50. Widdicombe JG. Sensory innervation of the lungs and airways. In: Cervero F, Morrison JFB, eds. Progress in Brain Research. Vol. 67. Visceral Sensation. Amsterdam, Elsevier, 1986; pp. 49-64.

51. Gaylor JB. The intrinsic nervous mechanism of the human lung. Brain 1934; 57: 143-160.

52. Karlsson J-A, Sant'Ambrogio G, Widdicombe JG. Afferent neural pathways in cough and reflex bronchoconstriction. J Appl Physiol 1988; 65: 1007-1023.

53. Tatar M, Webber SE, Widdicombe JG. Lung C-fibre receptor activation and defensive reflexes in anaesthetized cats. J Physiol 1988; 402: 411-420.

54. Stone RA, Worsdell Y-M, Fuller RW, Barnes PJ. Effects of 5-hydroxytryptamine and 5-hydroxytryptophan infusion on the human cough reflex. J Appl Physiol 1993; 74: 396-401.

55. Jackson DM, Norris AA, Eady RP. Nedocromil sodium and sensory nerves in the dog lung. Pulm Pharmacol 1989; 2: 179-184.

56. Tatar M, Sant'Ambrogio G, Sant'Ambrogio FB. Laryngeal and tracheobronchial cough in anesthetized dogs. $J$ Appl Physiol 1994; 76: 2672-2679.

57. Perl ER. Pain and nociception. In: Darian-Smith I, ed. Handbook of Physiology. Section 1. The Nervous System. Bethesda, American Physiological Society, 1984; 2nd edn. pp. 915-975.

58. Wall PD. The gate control theory of pain mechanisms: a re-examination and restatement. Brain 1978; 101: 1-18.

59. Paintal AS. Lung and airway receptors. In: Pallot DJ, ed. Control of Respiration. London, Croom Helm, 1983; pp. 78-107.

60. Eccles R. Menthol and related cooling compounds. $J$ Pharm Pharmacol 1994; 46: 618-630.

61. Sant'Ambrogio FB, Anderson JW, Sant'Ambrogio G. Effect of L-menthol on laryngeal receptors. J Appl Physiol 1991; 70: 788-793. 
62. Schafer K, Braun HA, Isenberg C. Effect of menthol on cold receptor activity. J Gen Physiol 1986; 88: 757-776.

63. Winning AJ, Hamilton RD, Shea SA, Guz A. Respiratory and cardiovascular effects of central and peripheral intravenous injections of capsaicin in man: evidence for pulmonary chemosensitivity. Clin Sci 1986; 71: 519526.

64. Armstrong DJ, Luck JC. A comparative study of irritant and type J receptors in the cat. Respir Physiol 1974; 21: $47-60$

65. Mohammed SP, Higenbottam TW, Adcock JJ. Effects of aerosol-applied capsaicin, histamine and prostagandin $\mathrm{E}_{2}$ on airway sensory receptors of anaesthetized cats. $J$ Physiol 1993; 9: 51-66.

66. Forsberg K, Karlsson J-A, Theodorssont E, Lundberg JM, Persson CGA. Cough and bronchoconstriction mediated by capsaicin-sensitive sensory neurons in the guinea-pig. Pulm Pharmacol 1988; 1: 33-39.

67. Karlsson JA. A role for capsaicin positive, tachykinin containing nerves in chronic coughing and sneezing, but not in asthma: a hypothesis. Thorax 1993; 48: 396-400.

68. Jancso G. Pathobiological reactions of C-fibre primary sensory neurones to peripheral nerve injury. Exp Physiol 1992; 77: 405-431.

69. Kohrogi H, Graf PD, Sekizawa K, Borson DB, Nadel JA. Neutral endopeptidase inhibitors potentiate substance $\mathrm{P}$ and capsaicin-induced cough in awake guinea-pigs. $J$ Clin Invest 1988; 82: 2063-2068.

70. Takahama K, Fuchikama T, Isohama Y, Kai H, Miyata T. Neurokinin A but not neurokinin B and substance P induces codeine-resistance coughs in awake guinea-pigs. Regul Pept 1993; 42: 236-237.

71. Katsumata U, Sekizawa K, Inoue H, Sasaki H, Takishima T. Inhibitory actions of procaterol, a beta ${ }_{2}$-stimulant, on substance P-induced cough in normal subjects during upper respiratory tract infection. Tohoku J Exp Med 1989; 158: 105-106.

72. Joos GF, Pauwels RA, Van Der Straeten ME. Effect of inhaled substance $\mathrm{P}$ and neurokinin $\mathrm{A}$ on the airways of normal and asthmatic subjects. Thorax 1987; 42: 779783.

73. Nadel JA. Modulation of neurogenic inflammation by peptidases. In: Kaliner MA, Barnes PJ, Kunkel GHH Baraniuk JN, eds. Neuropeptides in Respiratory Medicine. New York, Marcel Dekker, 1994; pp. 351-371.

74. Yoshihawa S, Kanno N, Ando T, et al. Involvement of substance $\mathrm{P}$ in the paroxysmal cough of pertussis. Regul Pept 1953; 46: 238-240.

75. Advenier C, Girand V, Naline E, Vilani P, Emonds-Alt X. Antitussive effect of SP 48968, a nonpeptide tachykinin $\mathrm{NK}_{2}$ receptor antagonist. Eur J Pharmacol 1992; 250: $169-173$.

76. Ujiie Y, Sekizawa K, Aikawa T, Sasaki H. Evidence for substance $\mathrm{P}$ as an endogenous substance causing cough in guinea-pigs. Am Rev Respir Dis 1993; 148: 16281632.

77. Ichinose $\mathrm{M}$, Nakajima $\mathrm{N}$, Takahashi $\mathrm{T}$, Yamanchi $\mathrm{H}$, Inoue $\mathrm{H}$, Takishima $\mathrm{T}$. Protection against bradykinininduced bronchoconstriction in asthmatic patients by neurokinin receptor antagonist. Lancet 1992; 340: 1248-1251.

78. Coleridge JCG, Coleridge HM. Afferent vagal C-fiber innervation of the lungs and airways and its functional significance. Rev Physiol Biochem Pharmacol 1984; 99: $1-110$.

79. Prabhakar NR, Runold M, Yamamoto Y, Lagercrantz H,
Cherniack NS, von Euler C. Roll of the vagal afferents in substance P-induced respiratory responses in anaesthetized rabbits. Acta Physiol Scand 1987; 131: 6371.

80. Coulter DM, Edwards IR. Cough associated with captopril and enalapril. Br Med J 1987; 294: 15211523.

81. Morice AH, Lowry R, Brown MJ, Higenbottam T. Angiotensin-converting enzyme and the cough reflex. Lancet 1987; 14: 1116-1118.

82. Ryu PD, Gerber G, Murase K, Randic M. Calcitonin gene-related peptide enhances calcium current of rat dorsal root ganglion neurones and spinal excitatory synaptic transmission. Neurosu Lett 1989; 89: 305-312.

83. Paintal AS. The visceral sensations - some basic mechanisms. In: Cervero F, Morrisson JFB, eds. Visceral Sensation. Amsterdam, Elsevier, 1986; pp. 3-19.

84. Irwin RS, Corrao WM, Pratter MR. Chronic persistent cough in the adult: the spectrum and frequency of causes and successful outcome of specific therapy. Am Rev Respir Dis 1981; 123: 413-417.

85. Banner AS. Cough. In: Simmone DH, ed. Current pulmonology. Chicago, Year Book Medical Publishers, 1988; p. 136.

86. Irwin RS, Rosen MJ, Braman SS. Cough: a comprehensive review. Arch Intern Med 1977; 137: 1186-1191.

87. Banner AS. Cough: physiology, evaluation and treatment. Lung 1986; 164: 79-92.

88. Irwin RS, Curley FJ, French CL. Chronic cough: the spectrum and frequency of causes, key components of diagnostic evaluation, and outcome of specific therapy. Am Rev Respir Dis 1990; 141: 640-647.

89. Boulet L-P, Milot J, Boulet M, St Georges F, Laviolette M. Airway inflammation in nonasthmatic subjects with chronic cough. Am J Respir Crit Care Med 1994; 149: 482-489.

90. Heino M, Juntunen-Backman K, Leijala M, Rapola J, Laitinen LA. Bronchial epithelial inflammation in children with chronic cough after early lower respiratory tract illness. Am Rev Respir Dis 1990; 141: 428-432.

91. Gibson PG, Dolovich J, Denburgh J, Ramsdale EH, Hargreave FE. Chronic cough: eosinophilic bronchitis without asthma. Lancet 1989; i: 1246-1347.

92. Curley FJ, Irwin RS, Pratter MR, et al. Cough and the common cold. Am Rev Respir Dis 1988; 138: 305311.

93. Irwin RS, Pratter MR, Holland PS, Corwin RW, Hughes JP. Postnasal drip causes cough and is associated with reversible upper airway obstruction. Chest 1984; 85: 346-352.

94. Corrao WM, Braman SS, Irwin RS. Chronic cough as the sole presenting manifestation of bronchial asthma. $N$ Engl J Med 1979; 300: 633-637.

95. Djukanovic R, Roche WR, Wilson J, et al. Mucosal inflammation in asthma. Am Rev Respir Dis 1990; 142: 434-457.

96. Irwin RS, Zawacki JK, Curley FJ, French CL, Hoffman PJ. Chronic cough as the sole presenting manifestation of gastroesophageal reflux. Am Rev Respir Dis 1989; 140: 1294-1300.

97. Irwin RS, French CL, Curley FJ, et al. The role of acid in the pathogenesis of chronic cough due to gastroesophageal reflux (Abstract). Am Rev Respir Dis 1991; 143: 534.

98. Ing AJ, Ngu MC, Breslin ABX. Pathogenesis of chronic persistent cough associated with gastroesophageal reflux. Am J Respir Crit Care Med 1994; 149: 160-167. 